http://kitaibelia.unideb.hu/

ISSN 2064-4507 (Online) • ISSN 1219-9672 (Print)

(C) Department of Botany, University of Debrecen, Hungary

25(2): 187-194.; 2020

DOI: $10.17542 /$ kit.25.187

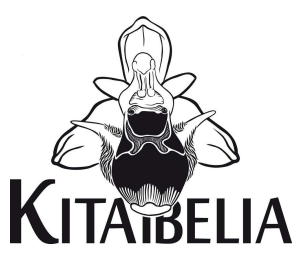

\title{
Kiegészítések a Soproni-hegység és előtere flórájának ismeretéhez II.
}

\author{
SCHMIDT Dávid* \& HASZONITS Győző \\ Soproni Egyetem, Erdőmérnöki Kar, Növénytani és Természetvédelmi Intézet, \\ H-9400 Sopron, Bajcsy-Zsilinszky u. 4.; *schmidt.david@uni-sopron.hu
}

\begin{abstract}
Notes to the vascular flora of Sopron Mountains and its foreground
Abstract - Records of 26 vascular plant species from the territory of Sopron Mountains (16 species) and Sopron Basin (11 species) are presented. Our field works (between 2014 and 2020) focused on some localities at the eastern and southern parts of the region. Tetragonolobus maritimus is new for the Sopron Mts, whereas Ajuga chamaepithys and Lycopsis arvensis are new for the Hungarian part of the hills. Some protected plants like Agrostemma githago, Gentianopsis ciliata and Sesleria uliginosa were rediscovered in the region. Comments about all species and their local chorology are added. A remarkable degradation process of bogs around Harka village, caused mainly by insufficient water supply of meadows, was observed. The spread of occurrences of several naturalized weed such as Aegilops cylindrica, Galium parisiense, Geranium rotundifolium, Kochia scoparia, Lepidium virginicum, Oenothera salicifolia, Sagina apetala subsp. apetala and Verbascum lychnitis was noticed. The most surprising observations refer to Galium parisiense; the spread of the species by transport had no precedent in Hungary before.
\end{abstract}

Keywords: floristic data, habitat change, rare species, Sopron Basin, Sopron Mountains, weed introduction

Összefoglalás - Közleményünkben a Soproni-hegység és Soproni-medence területén 2014 és 2020 között gyűjtött érdekesebb floriszikai adatokat adjuk közre. Felsorolásunkban összesen 26 taxon szerepel, 15 a Soproni-hegység, 10 a Soproni-medence területéről, egy további faj pedig mindkét területetről. Adataink közül kiemeljük a Soproni-hegységre nézve új Tetragonolobus maritimus előfordulását, a terület hazai felére nézve új Ajuga chamaepithys, Lycopsis arvensis előkerülését. Fontos eredmény az egyaránt védett, aktuális előfordulásokkal eddig nem rendelkező Agrostemma githago, Gentianopsis ciliata, valamint a Sesleria uliginosa egy újabb kis állományainak felfedezése. A Sopronimedence területéről nem közölték korábban a gyomjellegű Aegilops cylindrica, Galium parisiense, Geranium rotundifolium, Kochia scoparia, Lepidium virginicum, Oenothera salicifolia, Sagina apetala subsp. apetala, Verbascum lychnitis előfordulását, amelyek közleményünkben jelennek meg első ízben.

Kulcsszavak: behurcolás, élőhelyátalakulás, florisztikai adatok, ritka fajok, Soproni-hegység, Sopronimedence

\section{Bevezetés}

A Soproni-hegység flóraműve 2004-ben látott napvilágot. Flórajegyzéke (KIRÁLY et al. 2004) biztos alapot jelent a térségben folyó aktuális kutatásokhoz, bár nem tartalmaz teljes körű feldolgozást. Kiadása évében került elő a Pannonhalmi Bencés Főkönyvtárban Fászl István bencés hagyatékából a „Sopron flórája” című kézirat, amelyet a szerző a 19. század második felében állított össze (FÁszL \& BARTHA 2011). 
A 2000-es évek óta meglehetősen élénk Sopron környéki flórakutatás eredményeként a Soproni-hegység területére nézve új fajok kerültek kimutatásra (jelentősebbek például a Pseudolysimachion spurium, Melica picta (KIRÁLY et al. 2005), Ophrys sphegodes (HABERLER 2007), Alchemilla filicaulis (KIRÁLY \& KIRÁLY 2009), Orobanche teucrii (SCHMIDT et al. 2014), Festuca filiformis, Stipa eriocaulis (KIRÁLY \& KIRÁLY 2018), továbbá régi adatokkal rendelkező fajok lelőhelyeit sikerült megerősíteni. Utóbbiak közül kiemelhető a Phegopteris connectilis, Potentilla rupestris (KIRÁLY et al. 2005), Dianthus superbus, Orobanche elatior, Orobanche lutea (SCHMidT et al. 2014), Lathyrus nissolia, Viola elatior (MESTERHÁzy \& KUlCSÁr 2015). A hegység flórájával hagyományosan együtt tárgyalt Soproni-medence flórája ugyancsak számos újdonsággal bővült, itt azonban az egyre növekvő léptékben zajló élőhelyátalakítás (ipartelepek létesítése és bővítése, autóutak építése) következményeként szinte kizárólag az ember közvetítése nyomán újabban behurcolt, gyomjellegú elemek tűntek fel (pl. Amaranthus blitoides (SCHMIDT et al. 2014), Amaranthus deflexus (KIRÁLY \& KIRÁLY 2018), Geranium purpureum (SCHMIDT et al. 2014, KIRÁlY \& KIRÁLY 2018), Spergularia marina (SCHMIDT et al. 2018)). Fentieken túl, a Rubus nemzetség részletes feldolgozása az ismert fajok jelentős bővülését eredményezte a térségben (KIRÁLY et al. 2013, 2014, KIRÁLY 2018).

\section{Anyag és módszer}

Közleményünk - az első részben (SCHMIDT et al. 2014) megfogalmazott célokhoz hasonlóan a Soproni-hegység és a Soproni-medence flórájának ismeretét további új megfigyelésekkel egészíti ki. Terepi kutatásaink 2015 és 2020 között a két kistájnak csak egy részét érintették, célzott jelleggel elsősorban a Soproni-hegység déli és keleti peremének néhány érdekesebb területét (Harka: Istenszéke környéke, Harkai-plató; Ágfalva), valamint a Soproni-medence antropogén élőhelyeit kutattuk. Adataink túlnyomó többsége 2018-ból származik.

$\mathrm{Az}$ enumerációban felsorolt valamennyi rekord a Nyugat-magyarországi peremvidék földrajzi nagytájban (ezen belül az Alpokalja középtájban, valamint a Soproni-hegység kistájcsoportban) található. A lelőhelyeknél a kistáj (Soproni-hegység vagy Soproni-medence, rövidítve az Enumerációban $\mathbf{S H}$ illetve $\mathbf{S M}$ ) megadása mellett a településhatárt, és a pontos földrajzi helynevet is feltüntetjük. A helyneveket az 1:10 000 méretarányú EOV topográfiai térképről olvastuk le. A lelőhely után a termőhelyi körülményekre és az állomány méretére utaló információk szerepelnek, ezt követi a közép-európai flóratérképezés hálórendszerének (CEU/KEF) azonosító kódja, majd a megtalálás dátuma (legalább év pontossággal), a szerző monogramja (SD - Schmidt Dávid; HGy - Haszonits Győző; VD - Vojnić-Zelić Dániel) és a herbáriumi példány fellelhetősége (BP: Magyar Természettudományi Múzeum Növénytára). A taxonnevek KIRÁLY (2009) munkáját követik, felsorolásuk alfabetikus sorrendben történik. Közölt adataink feltöltésre kerültek Magyarország edényes növényfajainak online elterjedési atlaszába (AFH online, BARTHA et al. 2020).

\section{Eredmények}

Adataink közül kiemelendők a Harkai fás legelő egyik lápos mélyedésében előkerült kis Sesleria uliginosa állomány, valamint a terület túllegeltetett gyepjeiben talált Xanthium spinosum. Számos értékes fajt találtunk a soproni Lőtér feletti gyepekben, közülük kiemelendő a hegység területén mára bizonytalan előfordulásúként számon tartott Gentianopsis ciliata előkerülése. Harka és az országhatár között az Istenszéke xerotherm jellegű élőhelyein a Laitaicum flóráját idéző mészkedvelő fajokat találtunk (Ajuga chamaepithys, Lycopsis arvensis, Thymelaea passerina). Kimutattuk a védett Agrostemma githago egyetlen, kis egyedszámú 
állományát a Soproni-medencéből. A településflóra tanulmányozása során terjedőben lévő gyomnövények kerültek kimutatásra. Vasúti sínek mentén a térségben újonnan került elő az Aegilops cylindrica, Geranium rotundifolium, Lepidium virginicum és Oenothera salicifolia előfordulása, ugyanitt tömeges megjelenését regisztráltuk a Galium parisiense-nek.

További változásokra elsősorban a településflórában és más zavart élőhelyeken (pl. utak és vasutak mentén) lehet számítani, de a városi agglomeráció terjeszkedése (pl. Ágfalva, Brand-major és Harka térségében) egyre fokozottabb nyomást jelent a természetközeli élőhelyek állapotára is.

\section{Adatok felsorolása - Enumeráció}

Aegilops cylindrica Host - hengeres kecskebúza

SM: Sopron: a Csengery utca-Béke út közötti gyalogos vasúti átkelőben, a talpfák kövezése között 10-15 tő (8365.1, 2018, HGy; BP).

A Nyugat-Dunántúlon rendkívül ritkának számító gyom, bizonyított előfordulása csak a lövői vasútállomásról származik, ahol az első szerző egyetlen példányát találta a vasútállomás peronján (Schmidt D. ined. 2017 in AFH). Ennek a kontinentális jellegű dél-eurázsiaimediterrán fajnak (Soó 1973) az elterjedési határa a Kárpát-medence északnyugati részére esik. Eliáš et al. (2013) térképe szerint Alsó-Ausztriában még őshonos, ezzel szemben TÁBORSKÁ et al. (2015) kisalföldi adatát új behurcolásként, adventívként értékeli. Az idézett győri termőhelyén valóban csak átmeneti megtelepedőként volt jelen egyetlen évben (SCHмIDT 2010). Új soproni megfigyelése ugyancsak az adventív előfordulásokat bővíti.

Agrostemma githago L. - konkoly

SM: Harka: a településtől keletre, a Kert-mögötti-dűlő és a vasútvonal között, gabonavetés szélén, néhány tucat tő $(8365.4,2018, \mathrm{SD})$.

Nyugat-Dunántúlon ritka gyomnövény, a tájegység nyugati részéről PiNKE et al. (2005) mindössze néhány lelőhelyét ismerteti Kőszeghegyaljáról, a Kemeneshátról, Sopronhoz legközelebb Lövő mellől. Tómalomnál (Soprontól északra, a Fertőmelléki-dombsor része) KIRÁLY \& KIRÁLY (1999) élőhelymegadása alapján („kerítés tövén”) csak átmeneti megtelepedő volt.

Ajuga chamaepithys L. - kalinca ínfü

SH: Harka: Istenszéke, mélyút rézsűjén, zavart szárazgyepben (8365.3, 2018, SD \& VD).

Korábbi Sopron környéki említései KIRÁLY et al. (2004) szerint nem a hegységre, hanem a Fertőmelléki-dombságra vonatkoznak. Egyetlen biztos adata a harkai lelőhely közeléből, Neckenmarkt (Sopronnyék) meszes talajú gyomtársulásból származott (HoLzNER 1974).

Cuscuta campestris Yunck. - nagy aranka

SM: Kópháza: a határátkelő és a vasúti felüljáró között az út padkáján, elszórtan (8365.4, 2017, SD).

Alföldi elterjedési súlyponttal rendelkező, de országszerte jelentős terjedést mutató faj, amelyet BARTHA et al. (2015) térképe még ritkának tüntet fel a Nyugat-Dunántúlon. A célzott keresésnek köszönhetően újabban számos lelőhelyen találtuk a térségben, elsősorban autóutak, dűlőutak mentén (vö. az AFH térképét). Sopronból Soó (1968) közli, adatának pontos forrása nem ismert.

Dorycnium germanicum (Gremli) Rikli - selymes dárdahere

SH: Sopron: a Lőtér feletti félszáraz gyepekben helyenként tömeges (8365.3, 2018, SD).

Király in KIRÁLY et al. (2004) ugyaninnen még csak néhány tőről számol be. A Fertőmelléki-dombsor sztyepprétjein, száraz erdőszegély-gyepjeiben jellegzetes faj, a Soproni-hegység hazai oldalán azonban hiányoznak a növénynek kedvező élőhelyek, a fenti az egyetlen adata. 
Draba nemorosa L. - ligeti daravirág

SM: Harka: a Kenderes-dűlő és az országhatár közötti láprétek mezofil jellegű részén, elszór$\tan (8365.4,2016, \mathrm{SD})$.

Sopronban csak időleges megtelepedőként tartották számon (KIRÁLY et al. 2004). Egyes szakirodalmak (pl. SimON 2000) a növény élőhelyét száraz gyepekhez köti. Megfigyeléseink alapján megjelenhet üde és nedves rétek alig kiemelkedő hátain, sőt, olyan nedvesebb foltjain is, ahol a zárt gyep szövete sérült, felszakadt (pl. vakondtúrások, vaddisznótúrások helye). Ilyen környezetben gyakran más tavaszi keresztesekkel (pl. Arabidopsis thaliana, Cardamine parviflora, C. hirsuta, Erophila verna, Thlaspi arvense) és egyéves Veronica fajokkal társul.

Euphorbia verrucosa L. - bibircses kutyatej

SH: Sopron: a soproni Lőtér mellett, üde réten, kisebb állomány (8365.3, 2018, SD).

KIRÁLY (2004) elterjedési térképe nem tünteti fel a hegység déli részéből, de később jelentős állományát találták a Gida-patak menti gyepekben (Király \& Nagy in KIRÁLY et al. 2005). Új lelőhelye ettől mintegy 1,5 kilométerre nyugatra, a több más fontos félszárazgyepi és száraz erdőszegély-faj élőhelyét jelentő soproni Lőtér környéki gyepeken van. A faj jelentőségére KIRÁLY \& KIRÁLY (2006) hívta fel a figyelmet, akik mindössze néhány Sopron környéki és egy kőszeghegyaljai recens adatát sorolták fel, a közelmúltban pedig megerősítették déldunántúli meglétét (KIRÁLY \& KIRÁLY 2018).

Gagea pratensis L. s. l. - mezei tyúktaréj

SH: Sopron: a Harkai-plató félszáraz gyepjeiben, főként a Gida-patakot kísérő cserjés sáv mentén, elszórtan (8365.2, 2015-2018, SD).

Előfordulását a közeli Harkai-kúpról (Soproni-medence) előző cikkünkben közöltük (SchmidT et al. 2014).

Galium parisiense L. - párizsi galaj

SM: Sopron: GySEV-Déli-pályaudvar épületei és a Kossuth L. utcai vasúti átjáró között, vágányok mentén tömeges (8365.1, 2018-2020, SD, HGy \& VD; BP); a főpályaudvar ÉNy-i részén, vágányok között, kb. 10-15 tőből álló kisebb állomány (8365.2, 2018-2019, SD).

A faj hazánkban rendkívül ritka, BARTHA et al. (2015) mindössze 5 adatát ábrázolja. Flóraműveink őshonos elemnek tartják, BALOGH \& MESTERHÁZY (2017) szerint azonban DélEurópából hurcolódhatott be a legelő állatok által. Vasút mentén történő másodlagos fellépése egészen váratlan és minden előzmény nélküli hazánkban, ráadásul a megtalálás évében Vas megyében is többfelé regisztrálták (SCHMIDT 2019). Az előfordulás körülményei nem hagynak kétséget afelől, hogy vasúti szerelvények közvetítésével behurcolt állományokról van szó, amelyek 2020-ban is gazdag önfenntartó populációkkal voltak jelen.

Gentianopsis ciliata (L.) Ma - kései prémestárnics

SH: Sopron: a soproni lőtér feletti félszáraz gyepekben, 11 virágzó tő (8365.3, 2018, SD).

Néhány adattal rendelkezett a Soproni-hegység osztrák és magyar oldaláról is. Mind KÁRPÁTI (1938) sopronbánfalvi, mind TíMÁR \& SZMORAD (1996) Ikva menti adatának aktuális megléte az élőhelyüket érintő átalakulás miatt erősen kétséges.

Geranium rotundifolium L. - kereklevelű gólyaorr

SM: Sopron: Déli-pályaudvar, rakodóépület tövénél néhány tucat tő (8365.1, 2018-2020, SD; BP).

Sopron környékén nem őshonos, publikált adatát a Nyugat-magyarországi peremvidék nyugati részéről nem ismertük. Megjelenése újabb keletű behurcolás eredménye, amely nem egyszeri eset: 2018-ban előkerült Szombathelyen is, ugyancsak vasút mellett; SCHMIDT 2019). Sopronban a GySEV használaton kívüli Déli pályaudvara tolatóvágányai mentén, valamint a vasúti épületek környezetében több behurcolt faj is megtalálható, amelyek a területen viszszafogottan végzett gyomirtás hatására buján tenyésznek. Említést érdemel ugyanitt a töme- 
ges Buddleja davidii (virágzó, 1,5-2 méter magas egyedek), Geranium purpureum, Panicum riparium.

Helictotrichon adsurgens (Schur ex Simonk.) Conert - lapos zabfü

SH: Sopron: a soproni lötér feletti félszáraz gyepekben, néhány $\mathrm{m}^{2}$-es folton $(8365.3,2018$, SD).

Két közelmúltbéli megfigyelése közül az egyik erről a területről származik (Király 2002 in KIRÁLY et al. 2004), a fenti adat ennek a megerősítése. A Sánc-hegyi előfordulás (Király \& Nagy in KIRÁLY et al. 2005) a hegység északi részén található, de itt újabban nem találtuk.

Kochia scoparia (L.) Schrad - kerti seprőfü

SM: Sopron: az Ikva-Győri út kereszteződésétől 100 méterre a város irányába az útpadkán, 1 terebélyes tő (8365.2, 2018, HGy).

A faj az ország szárazabb alföldi területein elterjedt, főként erős antropogén hatás alatt álló termőhelyeken gyakori. Újabban a gyorsforgalmi autóutak közvetítésével terjeszkedik nyugat felé, többfelé megjelent Győr-Moson-Sopron és Vas megye újonnan épült autóútjai mentén (SCHMIDT 2019). BARTHA et al. (2015) még csak 6 kvadrátból jelzi a NyugatDunántúlról. Az újonnan épülő vonalas létesítmények melletti keskeny élőhelyfolyosókon határozott terjedésével kell számolni országszerte. Megjegyzendő, hogy a hazai határozók nem tárgyalják külön a kertekben gyakran ültetett tőalakot (subsp. scoparia), ami kivadulhat, de tartósan fennmaradó, terjedóképes állományokat ritkán hoz létre, szemben a helyenként már inváziós jellegú subsp. densiflora (Turcz. ex Aellen) Aellen-val. A Sopronban megfigyelt példány alfaji szintû meghatározása nem történt meg, de valószínúleg a subsp. densiflora-ról van szó.

Lepidium virginicum L. - amerikai zsázsa

SM: Sopron: Déli-pályaudvar, vasúti rakodóépület mellett, kavicsos-salakos talajfelszínen, több tucat tő (8365.1, 2020, SD).

A fajnak nem volt korábbi adata a Nyugat-Dunántúl északi részéről. KÁROLYI \& Pócs (1969) néhány, PINKE et al. (2005) egy lelőhelyét közli Zala megyéből, amihez a Flóraatlasz (BARTHA et al. 2015) tesz hozzá még két (szintén zalai) adatot. Új lelőhelyén a megtalálás előtti két évben szinte biztosan nem volt jelen, feltehetőleg egészen friss behurcolásról van szó. Nyugat-Dunántúl hasonló élőhelyein a L. densiflorum van terjedőben, helyenként már gyakori, és a soproni vasútállomás környékén is elterjedt.

Lycopsis arvensis $\mathrm{L}$. - vetési farkasszem

SH: Harka: Istenszéke, löszös útrézsűn, zavart szárazgyepben, néhány tő (8365.3; 2018; SD \& VD).

Hazánkban fokozottan veszélyeztetett szegetális gyom (PINKE 2008), amely a NyugatDunántúlon igen ritka: innen a Flóraatlasz (BARTHA et al. 2015) nem jelzi egyetlen adatát sem. KIRÁLY et al. (2004) csak a hegység ausztriai oldaláról sorolja fel, a hazai oldalra nézve új.

Oenothera salicifolia Desf. (syn.: Oe. depressa Greene) - magyar ligetszépe

SM: Sopron: Kőszegi úti vasúti aluljáró hídja mellett, sínek közötti kavicsos feltöltésen néhány tő (8365.2; 2018-2019; SD).

Könnyen azonosítható, ennek ellenére jelentősen alultérképezett faj hazánkban, amely elsősorban az ország szárazabb klímájú területein elterjedt, főként homoktalajon. Soproni megjelenése egyelőre átmeneti jellegűnek tűnik, állománya nem mutat terjedést. A területről korábban nem volt ismert. 
Orobanche gracilis Sm. - vérveres vajvirág

SH: Sopron: a soproni lőtér feletti félszáraz gyepekben, néhány tucat tő, Dorycnium germanicum-on (8365.3, 2018, SD); Harka: Harkai láprét, Lotus corniculatus-on (8365.4, 2019, SD).

Előfordulása a hegységben eddig csak az északi, hűvösebb klímájú területekről volt ismert (Hidegvíz-völgy rétjei, Arbesz-rét; KIRÁLY et al. 2004, SCHMIDT et al 2014).

Sagina apetala Ard. subsp. apetala - sziromtalan zöldhúr

SH: Sopron: Mikoviny utca és Hunyadi J. utca sarkán, térkövezett parkolóban a kövek közötti résekben (8365.1, 2020, SD).

SM: Sopron: Csengery utca, a vasútállomással szembeni bérház térkövezett udvarán, a kövek között (8365.2, 2020, SD).

Eredetileg mészkerülő szántók ritka, aprócska növénye, amely megfigyeléseink szerint az utóbbi években a $S$. procumbens-hez hasonlóan (amely mára közönségessé vált) a településeken egyre elterjedtebb díszkövezett felületek réseiben kezdett el terjedni. Sopron környékéről KIRÁLY et al. (2004) a Harkai-platóról említi taposott gyepekből.

Sesleria uliginosa Opiz - lápi nyúlfarkfű

SH: Sopron: Brandmajor közelében, a Gida-patak hídja mellett, rekettyefüzes közötti kisebb Molinietum-ban, 1-2 $\mathrm{m}^{2}$-es folton (8365.2, 2018, SD).

Korábbi jelzése erről a helyről nem volt. KIRÁLY et al. (2004) térképe Harka északi határából jelöli (élőhelye azóta megsemmisült), KÁRPÁTı (1938) a Gida-patak felsőbb szakasza melletti Béka-tavat említi, ahonnan már az ezredforduló előtt eltűnt. Megerősíthető előfordulása a Kecske-patak mentén Harkától délre (a Kenderes-dűlő és az országhatár között, az ún. Harkai-láprét területén, Soproni-medence), de itt az utóbbi időszak intenzív településfejlesztésének (telkesítés, beépítés) káros hatásai a láprét természetességi állapotát fokozatosan rontják. Emellett a felsőbb talajrétegek mind gyakoribbá váló kiszáradása is megfigyelhető, a fajkompozíció átalakulóban van, szembetűnő a mezofil gyepek füfajainak (magasabb térszíneken foltokban a Bromus erectus) előretörése.

Tetragonolobus maritimus (L.) Roth - szögletes bársonykerep

SH: Sopron: a Lőtér feletti félszáraz gyepekben elszórtan (8365.3, 2018, SD).

Megfelelő élőhelyek híján Sopron környékének praenoricumi területein igen ritka, egyetlen recens adatát Király in KIRÁLY et al. (2004) a Soproni-medencéből közli. A hegységből régi jelzései sem ismertek.

Trifolium fragiferum L. - eperhere

SH: Sopron: Brand-majortól északra, juhlegelő erősen taposott gyepjében (8365.2, 2018, SD).

A Soproni-hegységből csak egy régi jelzése van a Hidegvízvölgyből (BorosNÉ MuRÁNYI 1949), újabb publikált adata a Soproni-medencéből származik (Király in KIRÁLY et al. 2004: Harka).

Trifolium medium Grufb. in L. - erdei here

SH: Sopron: a soproni lőtér feletti félszáraz gyepekben bőven (8365.3, 2018, SD).

A Soproni-hegységben ritka faj, adatai a hazai oldalon kizárólag az északi hegységrészről voltak.

Trifolium ochroleucon Huds. - vajszínű here

SH: Sopron: Harkai-plató, erdőszéli cserjésedő félszáraz gyepekben, közel a kempinghez (8365.2, 2018, SD); a soproni lőtér mellett, félszáraz irtásréten (8365.3; 2018, SD).

KÁRPÁTI (1949) „a Harkai-fennsík füves helyein” találta, amely ráillik új lelőhelyeire is. Ezt követően mindössze egyetlen adatát publikálták a Városligeti-erdőből (Király 2002 in KIRÁLY et al. 2004). 
Thymelaea passerina L. - egynyári cicó

SH: Harka: Istenszéke, mélyút rézsűjén, zavart szárazgyepben (8365.3; 2018; SD \& VD).

A Flóraatlasz (BARTHA et al. 2015) térképe szerint a Nyugat-Dunántúlon igen szórványos, csak 10 kvadrátból tünteti fel. Sopron környékén a Laitaicumban elterjedtebb, a számára alkalmas (száraz, köves-homokos talajú) élőhelyek hiánya miatt a Soproni-hegységben igen ritka, KIRÁlY et al. (2004) mindössze egy lelőhelyét ismerteti. Mindkét ismert állománya a hegység délkeleti peremén található.

Verbascum lychnitis L. - csilláros ökörfarkkóró

SM: Sopron: Déli-pályaudvar vágányai között, 1 tő (8365.1, 2018, SD, HGy \& VD).

KIRÁLY (2009) határozója az egész országban szórványos előfordulású fajnak tartja, BARTHA et al. (2015) térképe szerint viszont a Nyugat-Dunántúlon igen ritka, ami a faj számára kedvező száraz, laza talajú gyeptársulások pontszerű előfordulásával magyarázható. Új soproni felbukkanása bizonyára behurcolás eredménye. A Soproni-medencéből korábban nem volt ismert (KIRÁLY et al. 2004).

Xanthium spinosum L. - szúrós szerbtövis

SH: Sopron: Brandmajor és Harka között, a Harkai fás legelő déli részén található juhtartó telep területén, erősen taposott helyeken, jelentős egyedszámban (8365.4; 2018, SD).

A juhnyáj napi járási útvonala mentén kisebb-nagyobb csoportjai szintén előfordulnak, magányos egyedét a teleptől 1200 méterre nyugatra a Várisi-erdő szélén is megfigyeltük (8365.2; 2018, SD). A fajt - régi források alapján - KIRÁLY et al. (2004) a lehetséges előfordulású, újabb megfigyeléssel nem rendelkező taxonok között sorolja fel, tévesen őshonosként feltüntetve. Utolsó jelzése Goмвосz (1906)-tól származik.

\section{Köszönetnyilvánítás}

A kézirathoz füzött kritikai észrevételekért köszönetünket fejezzük ki Bartha Dénesnek, és a cikk két bírálójának. A terepmunkában nyújtott segítségét Vojnić-Zelić Dánielnek köszönjük. Jelen publikáció az „EFOP-3.6.1-16-2016-00018 - A felsőoktatási rendszer K+F+I szerepvállalásának növelése intelligens szakosodás által Sopronban és Szombathelyen" című projekt támogatásával valósult meg.

\section{Irodalomjegyzék}

BALOgh L. \& Mesterházy A. (2017): Két új adventív faj előfordulása Magyarországon a buzérfélék (Rubiaceae) családjából. - Kitaibelia 22(2): 286-296.

BARThA D., BÁN M., SchmidT D. \& TiBorcz V. (2020): Magyarország edényes növényfajainak online elterjedési atlasza (http://floraatlasz.uni-sopron.hu). - Soproni Egyetem, Erdőmérnöki Kar, Növénytani és Természetvédelmi Intézet.

Bartha D., Király G., Schmidt D., Tiborcz V., Barina Z., Csiky J., JakAB G., LeSkU B., Schmotzer A., VidéKi R., Vojткó A. \& ZólYomi Sz. (szerk.) (2015): Magyarország edényes növényfajainak elterjedési atlasza. Nyugat-magyarországi Egyetem Kiadó, Sopron, 329 pp.

Borosné MuRÁNYI J. (1949): A Soproni Hidegvízvölgy flórája. - Erdészeti Kísérletek 49: 159-159.

Eliáš P. Jun., DítĚ D., Eliášová M. \& ĎuRIŠovÁ L. (2013): Distribution and origin of Aegilops species in Slovakia. - Thaiszia 23(2): 117-129.

FÁsZL I. \& BARTHA D. (2011): Sopron flórája. - Nyugat-magyarországi Egyetem Kiadó, Sopron, 75 pp.

Goмвосz E. (1906): Sopron vármegye növényföldrajza és flórája. - Mathematikai és Természettudományi Közlemények 28: 401-577.

HABERLER T. (2007): Ophrys sphegodes Miller a Soproni-hegységben. - Flora Pannonica 5: 188. 
Hohla M. (2013): Eragrostis amurensis, Euphorbia serpens und Lepidium latifolium - neu für Oberösterreich, sowie weitere Beiträge zur Flora Österreichs. - Stapfia 99: 35-51.

HolzNER W. (1974): Das Anthemido Ruthenicae - Sperguletum, eine eigenartige Ackerunkrautgesellschaft des mittleren Burgenlandes. - Wissenschaftliche Arbeiten aus dem Burgenland 53: 2130.

KÁRPÁTI Z. (1938): Érdekes és újabb növényelőfordulások Sopron környékén. - Soproni Szemle 2: 74-84.

KÁRPÁTI Z. (1949): Érdekes és újabb növényelőfordulások Sopron környékén III. - Erdészeti Kísérletek 49: 168-182.

KÁRolyi Á. \& Pócs T. (1969): Délnyugat-Dunántúl flórája II. - Acta Academiae Paedagogicae Agriensis 8: 469-495.

KIRÁLY G. (szerk.) (2004): A Soproni-hegység edényes flórája. - Flora Pannonica 2: 1-507.

KiRÁlY G. (szerk.) (2009): Új Magyar Füvészkönyv. Magyarország hajtásos növényei. Határozókulcsok. Aggteleki Nemzeti Park Igazgatóság, Jósvafő, 616 pp.

KIRÁLY G. (2018): Alien Rubus species in Hungary: distribution, habitats and threats. - Dendrobiology 80: 1-11.

KIRÁLY G. \& KirÁLY A. (1999): Adatok és kiegészítések a magyar flóra ismeretéhez. - Kitaibelia 4: 229246.

KiRÁlY G., CSAPODY I., SZMORAD F. \& TímÁR G. (2004): A Soproni-hegység edényes flórájának enumerációja. - In: KIRÁLY G. (szerk.): A Soproni-hegység edényes flórája. - Flora Pannonica 2: 91-474.

KIRÁLY G., NAGY A. \& KirÁLY A. (2005): Kiegészítések a Soproni-hegység és a Soproni-medence flórájának ismeretéhez. - Flora Pannonica 3: 41-48.

KiRÁlY G. \& KiRÁLY A. (2009): Új adatok az Alchemilla filicaulis Buser magyarországi előfordulásához. Flora Pannonica 7: 78.

KirÁly G., BARANYAI-NAGy A., KereKES Sz., KirÁLy A. \& KoRdA M. (2009): Kiegészítések a magyar adventívflóra ismeretéhez IV. - Flora Pannonica 7: 3-31.

KirÁly G., TRÁvNíčEK B. \& Žíla V. (2013): Revision of Rubus ser. Micantes occurring in Hungary and reevaluation of the neglected Rubus balatonicus. - Preslia 85: 505-526.

Pinke Gy. \& PÁL R. (2001): Adatok a Kisalföld gyomflórájának ismeretéhez. - Kitaibelia 6: 381-400.

Pinke Gy., PÁl R., Mesterházy A., Király G., Szendrődi V., Schmidt D., Ughy P. \& Schmidmajer Á. (2005): Adatok a Dunántúli-középhegység és a Nyugat-Magyarországi peremvidék gyomflórájának ismeretéhez II. - Kitaibelia 10(1): 154-185.

SchмiDT D. (2010): Adatok a Kisalföld flórájának ismeretéhez II. - Botanikai Közlemények 97(1-2): 79-95.

SchmidT D. (2019): Vonalas létesítmények mentén terjedő növények Vas megyében. - Vasi Szemle 73(2): 160-174.

SCHMidT D., NóTÁRI K. \& KoRDA M. (2014): Kiegészítő adatok a Soproni-hegység és előtere flórájához. Kitaibelia 19(2): 239-242.

SchmidT D., HASzonits Gy. \& KoRdA M. (2018): Sótűrő budavirágfajok terjedése a Dunántúl útjain. Kitaibelia 23(2): 141-150.

Simon T. (2000): A magyarországi edényes flóra határozója. 4., átdolgozott kiadás. - Tankönyvkiadó, Budapest, $976 \mathrm{pp}$.

Soó R. (1968): A magyar flóra és vegetáció rendszertani-növényföldrajzi kézikönyve III. - Akadémiai Kiadó, Budapest, $506+51$ pp.

Soó R. (1973): A magyar flóra és vegetáció rendszertani-növényföldrajzi kézikönyve V. - Akadémiai Kiadó, Budapest, 723 pp.

TÁborská J., VojtKó A., Dulai S. \& Schmotzer A. (2015): Distribution of Aegilops cylindrica Host in Hungary. - Thaiszia 25(1): 41-72.

TímÁR G. \& SzMORAD F. (1996): Új adatok a Soproni-hegység flórájához. - Kitaibelia 1(1): 17-24.

WALLNER I. (1903): Sopron környékén található virágos növények és edényes cryptogamok nevei és fajai. - Soproni Állami Föreáliskola Értesítője, 42 pp.

Beérkezett / received: 2020. 02. 20. • Elfogadva / accepted: 2020. 07. 08. 